\title{
Re-Reading Raphael Samuel: Politics, Personality and Performance \\ Introduction
}

For British historian Raphael Samuel (1934-1996), history was inextricable from politics. A former member of the Communist Party of Great Britain (CPGB) in his youth and later a key figure in the first British New Left (1956-1962), Samuel honed his craft at Ruskin College, Oxford, teaching social history to adult worker students. From here he launched the History Workshop movement (1967-1991) and the History Workshop Journal (HWJ) (1976). Viewing history as a social activity, an on-going process in which we are all implicated, the Workshop took its stance on the democratisation of history making. Decentring (but not abandoning) the text-based archive from its research, it embraced an inclusive historical pluralism, sensitive to the hidden histories in everyday life, inscribed upon objects, places and bodies or contained in oral memory.

In existing historiographical commentary, Samuel is an elusive and divisive figure. His work lacked 'scholarly' impact within the profession, he produced only one sole-authored monograph, Theatres of Memory (1994) which was not published by an academic press (published by Verso, formerly New Left Books) and did not set out a clear theoretical position. Further, his career lacked the traditional insignia of professional success, he occupied no prestigious chairs and held no honorary titles until the final year of his life.

Notably, what literature there is repeatedly acknowledges his unusual personality as much as his scholarly oeuvre. David Feldman and Jon Lawrence, for example, describe Samuel as the 'personification' of the History Workshop movement, his strong personal influence critical to its creative approaches to history (11. See also: Stedman Jones, 'The Independent'; Steedman, 53-55; Jones, 5-26; Kean, 51-62). Others viewed this sceptically, arguing that aspects of his personality were inhibitive to the development of a more rigorous analytical approach (Andrews, 80-101; Selbourne, 24; Kaye, 122; Dworkin, 192; Gentry, 187-211). Despite the different framing, both sets of comments recognised that his personality was an integral factor in shaping the Workshop's ethos and output (for better or for worse).

Much of the commentary from those closest to him further hints at a deliberately performative quality to his behaviour as an intellectual figure and leader. Sheila Rowbotham, an early Workshop participant, commented: 
Raphael was not simply a writer but a renowned organiser, the kind who was an initiator of great projects with a capacity to yoke his fellow to the concept and carry them on regardless of grizzles and groans. The deliberately dozy and slightly dotty front disguised an iron resolution (131).

The idea of 'performance' was reinforced by Alison Light's biographical account of her husband who, in more private moments, she depicted as a serious, even slightly haunted person:

He was a dedicated worker with an almost nineteenth century faith in the value of work, testing his capacities to the limits, often going without food or sleep [...] He could spend the day 'in a pit', rewriting the same sentence a hundred times, because, like so many others, he cherished the hope that if he could find the right word or phrase, the whole argument would be illuminated $[\ldots](\mathrm{xxi})$

This earnest image stands in contrast to the accounts of a gregarious and charming public figure.

This paper argues that the most radical aspect of Samuel's historical work was not its content or even its theoretical implications (although his contributions here were considerable), but his entire way of being a historian. For him, accepting history in the plural and democratising the production process required that he, as a historian, "concede the practice of democracy" in his personal attitudes and behaviour (Williams, 341). It is contended here that he consciously crafted an intellectual persona as a political tool for achieving short term aims and as a performative embodiment of his ideas.

To fully grasp his significance as a thinker requires an analytical approach sensitive to this form of embodied, applied thinking. Traditional approaches to intellectual history have tended to focus on the text as the key medium of intellectual expression and to gauge impact through text based markers such as citation or circulation figures. As Dwight Conquergood argued, these are not always attuned with meanings that are hidden in context, present but "not secured in print" (146).

An alternative is offered by performance theory, now a well-established field in the social sciences, ${ }^{1}$ which sets out a view of the 'self' as continually re-defined defined through social roles and contexts. Whilst presenting an important idea, some approaches to performance as

\footnotetext{
${ }^{1}$ Influential texts in this field include: Erving Goffman, The Presentation of Self in Everyday Life (1959) Richard Schechner, Performance Theory (1977), Pierre Bourdieu, The Logic of Practice (1980), Judith Butler, Bodies that Matter (1993).
} 
identity risk being too schematic in the application. Neither social contexts or individuals are enclosed spaces, they have porous boundaries, continually absorbing external influences. Nor, as Samuel himself argued, is the self a blank slate, reconstituted in each new social context, it retains an active memory of its other identities (or other histories), all of which shape the resulting performance (Samuel, Theatres, ix-x. See also de Certeau, 1984).

At the core of Samuel's political and historiographical project was the acknowledgement of different, interconnecting forms, spaces and experiences of knowledge (such as oral, visual, emotional). It is fitting then that a similar approach should be drawn upon when considering the man himself. Life writing, with its inherently holistic outlook, offers an indispensable tool for integrating these distinct dimensions of knowledge (Monk, 527-570). Methodologically, its malleability permits insight into contextual fluidity whilst the intimacy of its perspective illuminates the complexity underpinning outward appearance and inner motivations.

This paper first situates Samuel in the context of his earlier life, focusing on how and why he created such a public persona and how he adapted it in response to changing circumstances. It then considers the implications and effectiveness of this persona by assessing how it was perceived and narrated by others, acknowledging, in the process, why different groups engaged with and interpreted it differently.

\section{Childhood Communism, Activist Politics and Adult Education}

Samuel's early life pre-disposed him to an acute self-awareness of public perception. This awareness was a key tool in achieving his political objectives. I argue that during his years as a New Left activist, this disposition was transformed into a political end in its own right, further reinforced by his experiences as a young adult education tutor in a workers' college.

In taking a more intimate view of Samuel's early years I have drawn on his semiautobiographical essays The Lost World of British Communism (2006) and a series of interviews given to fellow historian and friend Brian Harrison (Harrison, 1979; "September" 1987; “October" 1987). These are difficult sources to handle. Lost World has an explicit agenda; it was a performative vehicle for Samuel's historiographical interests and politics, which, at the time, were focused on the impact of political belief on personal behaviour. In the work, the use of his own past is more illustrative of his arguments than revelatory or reflective. As Lynne Segal notes, his intensely micro-anthropological approach actually evaded any intimate self-disclosure (6-23). Conversely, as John Saville argued, it also obscured some of the broader contexts and chronologies in which its subject matter took place: "I do not deny 
the validity of Raphael Samuel's own personal history, especially in his younger days [...] The historian in him, however, might have acknowledged that it was a very unusual story [...]" (9).

Similarly, the interviews with Harrison, the first about oral history methodology and the second as part of Harrison's research into the social and cultural histories of the Oxford University left (226-271) took place at the time when Samuel was working on Lost World and was, therefore, acutely preoccupied with analysing political mentalities in popular culture. This may well have informed how he framed his answers. Another point to consider is the extent to which the interview format serves as a specific site of active self-creation, negotiated between interviewer and interviewee. Whilst Harrison was well known to him, and friendly towards the Workshop, he was not an 'insider' or a member of the radical left. Furthermore, as a history tutor at Oxford University during this time, Harrison was likely to look upon the radical elements of the workshop with reservation. So, even as Samuel described the need, as a member of the far left, to present a reasonable or 'palatable' persona in order to gain a hearing for his views, he was also repeating this in the interview context. In other words, they are part of the 'performance' this paper seeks to analyse.

Whilst this must be taken into account, the essays and the interviews also contain factual information, anecdotes of events and exchanges which took place. To counter interpretative slants, I have, where possible, checked these against other available sources.

Samuel was born into an extended Jewish family in North London. Immediately, this suggests that from an early age he became accustomed to a sense of difference and distance from mainstream English society, not only in terms of specific 'articles of faith' but of an entire cultural identity including the presence of different language, literature and customs. Ironically, Samuel reports that his mother, Minna Samuel, joined the CPGB in part to 'escape the ghetto' and join more fully into an English society, albeit from a countercultural perspective (63-68; May, "Minna Keal").

Minna joined the party in early 1939 (the last of her three sisters to do so). The timing here was significant. This was the communism of the 'popular front.' In 1935 the party, previously committed to the isolationist policy of 'class against class', responded to the growing threat posed by European fascism by shifting its line to popular frontism (Morgan, 33-55). Following this move, it enjoyed a steadily increasing membership, part of a wider groundswell of popular political activity fuelled, in part, by the outbreak of the Spanish Civil War (1936). This sort of grass-roots activism was more dependent on inter-personal relations between the participant 
individuals than on an overarching theoretical position. In the CPGB, party members came under considerable pressure to forge alliances with other groups and to maintain a high level of public presence and activity. Minna took to these sorts of roles with gusto becoming a proactive party organiser (Samuel, Lost World 63-68; Light, 24).

Samuel followed his mother in aspiring to the role of the organiser. In Lost World he supplied readers with descriptions of the nature and the implications of these sorts of more practical 'activist-leadership' roles in the Party drawing on both his personal experiences and official Party documentation (italics added):

In the localities, too, authority was expected to be self-effacing. Branch secretaries were expected to comport themselves as co-workers, taking on a good deal of the dogsbody work, as the price of the trust which reposed in them. At branch meetings he/she was to exercise a pastoral care, drawing the members in by allocating tasks to them, 'involving' them in the processes of decision making [...] encouraging new comers to 'express' themselves (125)

and:

One started at the 'level' of the sympathiser, emphasising common ground, 'building' on particular issues, while at the same time investing them with Party-mindedness. Plied with Party literature, invited to Party meetings, above all 'involved' in some species of Party work $[\ldots]$ the sympathiser was drawn into the comradeship of the Party by a hundred subtle threats $(125-126)$

The role described by Samuel has some notable features. Firstly, it was acutely social, dealing directly with people. Secondly, it required the individual in question to have a clear consciousness of their own performance in relation to the people they were dealing with, comporting themselves as a co-worker, being welcoming and inclusive. Thirdly, much depended upon the individual's ability to synthesise different areas of expertise into a collective endeavour and identify areas of common ground between their interests and the person(s) they were engaging with. Finally, it called upon skills in using that common ground as a basis for infusing the subject with 'party mindedness', to provoke an internal transformation, all the more plausible and effective because the subject was actively complicit in the process. To summarise, the role drew on forms of intelligence and skill both pragmatic and profoundly psychological in character. 
For Samuel, however, reaching young adulthood in the late 1940s and 1950s, his own communist sensibilities were shaped in a very different political context defined by the Cold War. The most immediate effect of this geo-political stand-off was an atmosphere of increased suspicion and hostility (H. Jones, 24-26), demanding from party members (particularly those attempting to recruit for the party), an even greater self-awareness. In his interviews with Harrison, Samuel described the situation he faced as an undergraduate student at Balliol College, Oxford University (1952-1956):

I mean there wouldn't be a minute that I wouldn't be aware that I was a Communist until I left the Communist Party at 22. Anything I did, there would always be a kind of sense that it was in some way forwarding the cause - even if it was something like playing football or tennis or shove ha'penny or just sitting around, because even making oneself agreeable was in some sense making one's unpalatable politics more palatable. [...] There was a sense of wanting to make the unpalatable palatable by showing a human face. Given that you actually had a politics that was zealous, the one thing you didn't do [...] in the Communist Party was be zealous about it because you wouldn't get a hearing for it in a hostile climate (“October" 17028).

Not only did he consciously adopt an agreeable persona, he applied this directly to political 'opponents', even drawing on an element of comedy in order to engage them in political discussion:

I mean, I actually liked arguing with Tories, and we used to get quite a lot of fun -in a wayalmost as court jesters. It was quite an improbable thing for anybody to be a Communist and they were very tolerant of us, and we were delighted to be tolerated, at the same time as working quite seriously to build up the readership of the Daily Worker (“October" 17028).

John Keegan, a Balliol contemporary and self-described Tory, recalled:

The Balliol Tories, who included at least two future cabinet ministers, took collective fun in mocking the difficulties into which Soviet policy landed him, but as individuals they respected his humanity and enjoyed his friendship. Ralph, despite the extremity of his views, was always ready to seek common ground with his political opponents and was delighted when he found it (21).

Samuel's approach to politics was an intimate one involving "a very concentrated effort of persuasion, and also of personal friendship" (Harrison, "September" 17591). The close relationships he formed with figures such as Stuart Hall, Charles Taylor, Gabriel Pearson and 
Peter Sedgwick, for example, formed the basis for setting up the subsequent first New Left movement.

Another anecdote from his student days gives a further glimpse of the complex and sophisticated inter-personal skills required to achieve a hearing and claim a recruit. In later years, he recounted his extraordinary efforts to recruit Dennis Butt, a mature student and lifelong labour man, to the party. To achieve his ends, Samuel cultivated an intimate relationship with Butt, immersing himself in the cultural, psychological and emotional values of Labour politics. Along with the 'languages' of Labour, its social and cultural forms, he also encountered the personal dimensions of the commitment, how, for example, supporting the Labour party travelled down family lines, passing from generation to generation. It was only through such deep comprehension that he could find the means to present communism to Butt as something familiar and desirable. Ultimately, after a year of effort, he was successful in recruiting his man on Labour ground. He was not, however, untouched by this process, as he put it: "I actually, without knowing it, made myself into a kind of Labour person" (Harrison, "October" 17030), an important reminder that such an intense act of persuasion left its mark on his state of mind.

If his activist youth had given him an awareness of self-deportment and skills in selfpresentation, these were still a means towards the end of recruiting people to the CPGB or furthering the cause. As an activist in the first New Left (1956-1962), they increasingly became integral to his entire conception of socialist politics. Following fellow comrades and contemporaries Edward Thompson and John Saville, Samuel, with some reluctance, formally left the CPGB following Nikita Khrushchev's revelatory speech and the Soviet invasion of Hungary in November 1956. Whilst disillusioned with party politics, his political instincts remained undiminished and he quickly became a galvanising figure in the New Left. ${ }^{2}$

The first New Left was expansive and multi-faceted. This paper refers to the group of intellectuals clustered around the journals The New Reasoner (NR), edited by Thompson and Saville and Universities and Left Review $(U L R)$ edited by Hall, Pearson, Samuel and Taylor.

\footnotetext{
${ }^{2}$ For overviews of the personnel and political preoccupations of the British First New Left see: Lin Chun, The First British New Left (Edinburgh, Edinburgh University Press, 1993); Michael Kenny, The First New Left: British Intellectuals After Stalin (London: Lawrence and Wishart, 1995); Dorothy Thompson, 'On the Trail of the First New Left', New Left Review, I/215, Jan-Feb (1996): 93-100; Dennis Dworkin, 'Socialism at Full Stretch', 'Culture is Ordinary', Cultural Marxism in Postwar Britain: History, the New Left, and the Origins of Cultural Studies (Durham: London: Duke University Press, 1997), 45-124; Stuart Hall, 'The Life and Times of the First New Left', New Left Review, 61, Jan-Feb (2010): 177-196; Wade Mathews, The New Left, National Identity and the Break Up of Britain (Leiden: Boston: BRILL, 2013).
} 
The New Left was both a product and a response to its times. In the short term it was prompted not only by the Soviet Union issue (although, arguably, this was a crucial motivation for figures such as Thompson, Saville and Samuel, all former communists) but also to the Suez crisis (1956), the inability of the British Labour party to assert itself as a political force and the impending threat of nuclear war (the New Left was closely allied to the CND movement). In the long term, it addressed the 'age of affluence' and the visible signs of social and cultural change in late 1950s Britain. ${ }^{3}$

The individual took on a renewed importance in the New Left's political imagination. Taking 'socialist humanism' as its key conceptual stand, it placed a greater stress on human agency and moral responsibility (Thompson, "Socialist Humanism”, 105-143), further reinforced by the centrality of culture onits intellectual agenda. Another defining characteristic was the drive to revitalise popular movement politics, or as Madeleine Davis described it, "activist politics" (57-81). The theoretical implications of this was to make politics personal, implicit within attitudes and behaviour. Practically, pursuit of a decentred activist politics, without the infrastructure of a party to fall back on, increased the pressure on individual personalities to continually inspire and sustain political activity. It was here that Samuel, the grass-roots organiser, flourished.

For Davis, Hall and Raymond Williams were the key figureheads behind this shift but as an interview conducted by the author with Hall (May 2012) and Samuel's personal papers reveal ${ }^{4}$, it was Samuel who played the most strategic role in bringing this about, driving the creation of the $U L R$ and fashioning its shape and form. Two weeks after leaving the CPGB, he wrote to Hall outlining his vision for the journal:

[T] he magazine should be designed to appeal to left wing dons especially younger dons - and the more active left wing students. In addition if we can give it a fair amount of ideological content it should appeal to ex University Lefts, to Ex Communists (recent) and liberal Communists still fighting inside the $\mathrm{CP}$ (people like Hill and Hobsbawm) and to left intellectuals generally. (15 ${ }^{\text {th }}$ November, ' 1956 ', RSA)

He continued, devising strategies for how it would facilitate network development:

\footnotetext{
${ }^{3}$ For overviews of the British political, social and cultural landscape of this period see Lawrence Black, The Political Culture of the Left in Affluent Britain 1951-64: Old Labour, New Britain? (London: Palgrave Macmillan, 2003); Peter Henessey, Having it so Good: Britain in the Fifties (London: Penguin, 2007). ${ }^{4}$ These are stored in the Raphael Samuel Archive, Bishopsgate Institute, London. Henceforth referred to as RSA.
} 
It seems to me that the only way to provide for the interests of such diverse groups of readers as those listed above is by printing a large number of readers' letters in each issue. I think we should aim at printing a minimum of fifteen readers' letters in each issue. A great advantage of printing so many letters is that people who have had letters printed tend to buy and sell the magazine. By printing a large number of letters we could build up a large network in every University and technical college. If we could have fifteen letters on say ten different topics we could show the range of interest offered by the magazine ( $15^{\text {th }}$ November, ' 1956 ', RSA)

He went on, setting out editorial roles ("yourself and myself as editors. Gary as literary editor. Chuck as ideological editor"), discussing details such as layout, printing costs and issues regarding distribution ( $15^{\text {th }}$ November, ' 1956 ', RSA). ${ }^{5}$ He advanced clear proposals for the contents of the first edition. Whilst permitting 'Gary' editorial determination over the literary section (no more than three or four pages here), he intervened rather more comprehensively on the ideological section, supposedly to be overseen by 'Chuck', listing what he thought would be appropriate. In total, he made twenty-two 'possible' suggestions for topics and authors including:

The Future of Marxism: An intermediate statement, Eric Hobsbawm; Labour Re-think Economics, Joan Robinson; French Intellectuals and the French Working Class, J.P Sartre; The Class Structure of Britain Today, Stewart Hall; Oxford Philosophy and Socialism, Chuck Taylor; The Marxist view of History: Can it be modified, Ralph Samuel; and Labour Careerism, Thomas Balogh (RSA, 15 ${ }^{\text {th }}$ November, 1956).

In a second letter, another two weeks after the first, he reaffirmed his view of the main aim, and ethos, of the journal:

one of our most important tasks will be to create a new mass basis in the Universities for socialist ideas - to greatly enlarge the numbers of those keenly interested in problems of rethinking, to take the discussion out of the relatively narrow circle of LP, CP and Fabian activists in which the discussion is at present confined. $\left(1^{\text {st }}\right.$ December, '1956', RSA).

The first edition shows how fully his blueprint was realised. ${ }^{6}$ Significantly, for all the rigour and initiative shown in his planning, he was the only one of the four young editors not to contribute a sole-authored article articulating his political views to the first issue (the promised article on the Marxist conception of history was never written).

\footnotetext{
5 'Gary' is an anglicised version of Gabriel (Pearson). Chuck refers to Charles Taylor.

6 'Editorial and Contents', Universities and Left Review, 1 (1957): 1.
} 
The letters reveal how Samuel worked as the unseen, but all pervasive, architect of the journal, with no detail of format, content and distribution deemed insignificant or beneath his notice. His lack of an explicit written piece kept him out of the argumentative fray but left him free to facilitate it, enacting the New Left demand for an participatory discussion rather than calling for it. He continued to express his position through his actions, assuming a key editorial function as the primary contact for all submissions to the journal, quickly expanding this organisational role into becoming the chairman of a network of New Left clubs and the driving force behind the Partisan Café, London's first 'anti espresso' coffee shop.

'Behind the scenes' organisational work of this nature was not far removed from his previous incarnation as communist organiser which had also involved creating inclusive spaces, drawing people in and 'involving' them in decision making whilst appearing as a co-worker and taking on 'dogsbody' work (Samuel, 125). On the other hand, this was not just a retreat to the political work he knew best, increasingly it was coming to define his political ideas.

A further illustration of this can be seen in his response to Thompson's article, 'Socialism and the Intellectuals', which appeared in the first edition of the ULR (1957). In it, Thompson pressed the case for British intellectuals to revitalise their political commitment, saying:

Goodness knows that human reason and conscience are imperfect instruments enough; they glow fitfully amongst the bric-a-brac piled all around, which threaten at any moment to topple over and extinguish their light - self-interest and self-esteem, indigestion, guilt, class conditioning, memories of the woodshed, old superstition, the lot. But we continue our intellectual work because we believe that, in the last analysis, ideas matter. (33)

Whilst Thompson's intellectual depended on the cultural authority necessary to rise above the 'bric a brac', Samuel rejected what he saw as the elitism implied by such a role. Again, his reply came indirectly, buried in a modest 'New Left notebook' entry, in which he argued that socialism 'sent down' from above was a 'libel' on the whole tradition. By contrast, he pointed instead to the collaborative, discursive role of the clubs (which, of course, was carried out under the careful 'guidance' of their chairman) as exemplary of real socialist intellectual work (79$80)$.

Samuel's personality was so central to the organisational structure of the first New Left that it proved as inhibitive as it did creative. Whilst, a gifted ideas man, as a practical administrator he was disastrous. He did not lay down any lasting infrastructure that others could use without his presence. After he drifted away from the clubs, they slowly declined. The Partisan café, forced 
through against his friends' wishes (Hall, 122), was financially disastrous. His temporary editorship of the New Left Review (April 1962), following the resignation of Hall, resulted in a brilliant edition, but one that was late, over long and over budget.

After the break-up of the first New Left, Samuel took a job as a tutor at Ruskin College where he taught sociology and later social history to adult worker students. Here again was another context demanding strong personal and performative skills. The students, many of whom had not been in formal education, for many years, were often unconfident or suspicious of authority. On arriving at Ruskin, Samuel felt the College's existing infrastructure to be compounding this problem, as he said to Harrison:

When I started to teach at Ruskin I was very shocked at the ways in which students were treated, adult students, worker students. And they were treated as being sort of under privileged, educationally retarded people who had somehow or other to be dragged up to the level of grammar school university entrance (11836).

In addition to this, his early years of teaching took place against the political backdrop of the mid 1960s, a period of increasing confidence and challenge amongst the political left, particularly through an enlarged student body. ${ }^{7}$ Much of this activity focused on questioning and challenging traditional sites of authority, including the role of the teacher.

Samuel had, therefore, to use his personality to two ends: as a practical, pedagogical tool to gain the trust and co-operation of an often politicised and suspicious student body, and as a political statement where his outward behaviour and deportment embodied a clear differentiation from the traditional authority role of the tutor. The Workshop's emphasis on working class lives and popular culture emerged as a direct result of Samuel's desire to connect his student's personal experiences to their study of social and political history (Samuel, 'Afterword', 410-417), something which later brought it into conflict with other emerging critical political agendas (Schwarz, 202-220).

There are two key questions arising from Samuel's and others' representation of his formative years. Firstly, the extent to which self-consciousness of public persona was an embedded part of his childhood and young adulthood, both through his positioning as a member of a Jewish

\footnotetext{
${ }^{7}$ For memoirs of this period in Oxford see Sheila Rowbotham, Promises of A Dream (Penguin, 2000); Bob Purdie, "Long haired intellectuals and busy bodies": Ruskin, student radicalism, and civil rights in Northern Ireland', in G. Andrews, H. Kean and J. Thompson, eds., Ruskin College: Contesting Knowledge, Dissenting Politics (London: Lawrence and Wishart, 1999), 58-79.
} 
family in 1930s English society, as a member of a minority political party within a hostile climate and the internal expectations on behaviour enforced within that party. This was further reinforced by his own coveted party roles of organiser and recruiter. All of this required not only self-awareness about how he presented himself within different contexts, but also that he continually used his personality strategically, as a tool to aid in the achievement of his political ends such as gaining a hearing for his views or a recruit for the party.

Secondly, following his departure from the CPGB and his role in the first New Left, what had previously been a 'means to an end' now became a political end in itself as key strands of New Left critique focused on popular mentalities and its main activities emphasised popular engagement and active political participation, themes that similarly characterised his experiences as a young tutor at Ruskin College in the early to mid-1960s.

\section{Re-reading Samuel}

In this section, I turn to how Samuel's public persona was perceived or 'read' by colleagues, students and critics. It is, therefore, focused on Samuel as a symbolic figure. In making this analysis I have predominantly drawn upon tributes published shortly after his death in 1996. Amongst these are contributions from close friends, former colleagues and students, associates and family members. ${ }^{8}$ Some are brief articles and others short essays. Several were published in mainstream media outlets with a few appearing in periodicals or specialist journals. The writers were mostly men, with contributions from two women, Rowbotham and Carolyn Steedman. The contributors include academic and non-academic historians, journalists, writers, a Labour party politician and political/community activists.

Tributes and obituaries are a key site for 'myth making' in which certain traits are exaggerated whilst others are reduced and de-contextualised. For the purposes of this paper, which argues that Samuel consciously inscribed his political ideals into his public persona (and, consequently, that he, with some degree of deliberation, enabled this myth-making), this 'mythologising' is a useful source for gauging both the success and otherwise of Samuel's conscious efforts to convey his ideas through his physical being. The common features across the stories such as repeated references to specific traits or modes of behaviour or recurring

\footnotetext{
${ }^{8}$ Several of these were later collected together into a privately published and distributed book Raphael Samuel: Tributes and Appreciations (1997). A copy is held in the Raphael Samuel Archives.
} 
patterns in the descriptive or metaphoric language used to describe him are all indicative of how this appeared to observers of his outward behaviour.

Myth making is not a passive process but a dynamic one, constantly subject to modification. By considering a range of accounts of Samuel by different writers, with different relationships to him, it becomes clear that the image of the man was subject to negotiation, as contested as it was reinforced. Importantly, all the accounts, especially the critical ones, were still forced to respond to the myths, (even if this was only to deny them outright), indicating just how compelling and pervasive they were. In order to provide a diverse range of perspectives, I have also referred to critical reviews of Samuel's work written both during his lifetime and shortly after his death.

Among the most striking and recurrent features of the Samuel tributes are references made to his distinctive physical appearance (Schwarz 16; Jones 1; Prescott 16; Pilmott 7; Keegan 21; Hall 119-127). Not only does this warrant a considerable space, often commanding an entire paragraph, but these descriptions also constitute some of the most imaginative writing. This, for example from Schwarz, a former workshopper and $H W J$ editor:

Consistently unkempt, he lived a life of the mind, while physically possessing the air of an insomniac and a metabolism, which seemed impatient to burn up the calories the moment they entered his body. I have always thought of him as more diminutive than he actually was, pitted against odds larger than he (16).

Written with warmth and humour, Schwarz's invocation of a man apparently careless of his personal appearance, preferring instead the "life of the mind", and giving the impression of smallness all contributed towards an image of Samuel as an ephemeral or otherworldly character. References to insomnia and a ravenous metabolism create a sense of urgency and energy. The attributes described in this account found echoes elsewhere such as this from Mervyn Jones, a left-wing journalist and writer:

In appearance, and in his clothing, which was casual to the point of improvisation, Samuel never changed. His long wildly straying hair and his narrow eager face were perfectly right for his fervent, restless personality [...] In later years he was described as looking like a 1960s character, but perhaps he was more like a Bohemian of the era of Baudelaire (1).

Jones followed Schwarz in his depiction of Samuel as constantly in the midst of endless, frenetic movement and mirrored the affectionate amusement of the writing style. Jones added 
to his account a note of glamour, of 'bohemianism' (a recurrent word choice across several of the accounts) furnishing the picture with a sense of Samuel as exercising a species of selfconscious aestheticism about his person.

Another aspect of Samuel's physical presence and performative qualities that was much remarked upon was his style of lecturing. Schwarz again: "Like a fairground magician he would pick, as if at random, from a profusion of files and books and scraps of paper, nipping from pile to pile, delighted to share the fruits of his research with his audience" (16). This oft repeated anecdote was important for its ability to emphasise the theatrical qualities of the performance and further reinforce the self-consciousness involved in this process. Rowbotham, however, provided another perspective:

I went to hear Raphael again [...] This time he didn't pull it off. He spoke on Tawney and again had great piles of paper, but somehow lost the thread and simply rambled. This figure, who was capable of brilliant hits and meandering misses (126).

These descriptions frame Samuel's self-deportment with a strong comic quality, a compelling performer with flare and audacity but also a flawed one whose performances were not consistent and who displayed conceit in his refusal to stick to any protocols of lectureship. Hall, his university comrade and life-long friend (giving him ample opportunity to see this in action), provided another, more unsettling dimension to Samuel's performative capacities:

His passionate intensity was overwhelming. He could fix you with his deep, dark eyes and, especially when he was trying to persuade you about the unpersuadable, his voice would acquire a deep, rich seductiveness and gradually what you had originally thought to be your 'better judgement' would slowly melt away (125).

Here, the humour of the previous accounts is replaced with something more predatory and even slightly sexual in nature.

An important point to consider is that many of these accounts were written by fellow intellectuals all of whom were university educated and some of whom, at the time of writing, were themselves based in or around university departments. In their awareness and subsequent emphasis of their subject's eccentricities, the accounts draw, to an extent, a silent contrast to the more reserved deportment, style and behaviour more commonly associated with intellectual or scholarly life, appreciating, even enjoying, Samuel's disruption of the 'norm.' 
In several of the instances cited, such enjoyment is suggested by the way in which the writing rises to the challenge. Much of it dispensed with the sort of reverence that might be expected in an obituary, just as Samuel had dispensed with the formalities of professional academic life. They mirrored instead the humorous qualities of the man, drawing on colourful, imaginative similes and metaphors such as Schwarz's reference to a 'fairground magician'.

The tributes written by former students tended, by contrast, to be more focused and eloquent on other elements of Samuel's persona, specifically his kindliness. This contrast reveals both his capacity to adapt or tailor elements of his 'performance' according to the needs of the audience but also something of the nature of those needs. Take this, for example, from John Prescott, the former British Deputy Prime Minister, a Ruskin student during the mid-1960s.

He had this tremendous understanding of the inner inferiority that mature students have in a society that tells them they've missed out. He not only understood what was inside the student, he unlocked it and channelled it in written and verbal debate. There wasn't an ounce of superiority in him. In those tutorials he was often as much the student as the lecturer. He learned from you and you learned from him. He was fascinated by other people's experience (16).

This view found echoes in other student accounts. Showing that this approach was a consistent one throughout Samuel's teaching career, Paul Martin, a student during the 1980s, remembered a "self effacing man" who preferred to "hear and talk about what others were doing." On hearing him talk about labour history Martin said: "I immediately felt safe at Ruskin [...] Raph was the first person in any authority I had encountered to whom I immediately ideologically related, or who I felt thought like me" (146-147).

The student writers offset what they recognised of their own weaknesses and insecurities with their appreciation of Samuel's sensitive handling of them. Elsewhere, this 'sensitivity' was viewed more critically. David Selbourne, a former Ruskin colleague, offered a more unusual tribute:

Samuel embodied a peculiar style of privileged patronisation of working people $[\ldots]$ He often seemed a kind vicarious proletarian himself, romanticising the lives and labours of the industrial working class whilst flattering as well as encouraging his students. This often silly class condescension was an uncomfortable thing to observe (24).

Some years earlier, Patrick Wright, whose book Living in an Old Country (1985) was subject to pillory in Samuel's Theatres of Memory (1994), expressed bewilderment at the speed at 
which Samuel had shifted from being a staunch critic of heritage to its champion. Like Selbourne, Wright suggested that this owed much to Samuel's desire to 'play the part' of the people's historian (29).

If Selbourne and Wright had found Samuel's performance disingenuous, Richard Hoggart, a former New Left contemporary, offered an alternative but no less critical perspective in his review of Samuel's Theatre of Memory (1994). Hoggart, then chairmen of UNESCO, lamented what he saw as the book's 'relativist' stance towards representations of the past in popular culture. He suggested that Samuel's eagerness to embrace populist accounts of history was the product of a 'traumatised' Marxist, caught between his personal quarrels; with the past, with the left and above all with himself (215-216.).

Whether positive (accounts suggesting Samuel's behaviour showed sensitivity and kindly interest) or negative (accounts contending Samuel's behaviour indicated affectation or personal confusion), the various accounts all acknowledge his desire to empathise or even overempathise with his working class students. This suggests the malleability in his performance and ability to 'read his audience' Hall, again, provided insight:

He knew an astonishing range and variety of people each of whom at some point he had engaged in a searching conversation about their background, their families, their work, their life as I preparing everyone for the possibility of becoming another subject of an oral historical. He quarried their lives as he quarried old bookshops around the East End [...] Consequently, many people who had only a relatively short personal acquaintance with him, felt attached to him by the warmth and intensity of his relationship to them (125).

Presenting a personable demeanour and cultivating extremely close intimate relationships may have constituted some of his key methodologies, but what of the purpose behind them? As Rowbotham (quoted earlier) remarks, a sense of dualism, of a differentiation between surface appearance and deeper intention, was another strand running throughout many of the depictions of Samuel. Aside from Rowbotham, Hall spoke diplomatically of a capacity for 're-invention' and Schwarz drew upon a mythological reference with "Prometheus," the Greek demi-god, typically portrayed as a trickster character, who stole fire from the Gods to give to humankind (Hall 126; Schwarz 16). NB 'Promethean' also means something like radically original.

Despite the implications of trickery, this, for the most part, was tolerated because it was deemed to be well-intentioned, designed to encourage and galvanise people into becoming producers of their own history. In these examples, all provided by long-term friends and fellow 
intellectuals, it is described with affection and a warm knowingness (the extent to which this knowingness was a product of hindsight rather than of contemporaneous awareness cannot be so easily discerned). The framing of these accounts suggest that this was both a commonly perceived facet of Samuel's personality but also an opportunity for the various authors to signal that they were not (or no longer) 'taken in' by the performance. They were, however, willing to be indulgent, to admire its audacity and to be, to some degree, complicit in its perpetuation.

A few of the tributes, however, took a more serious view of Samuel's concealed agenda, seeing it in relation to his intellectual acuity, a feature often obscured or overshadowed by the romantic and comedic aspects of his performance, as noted by the others. Robin Blackburn, a former New Left club member and later the editor of the New Left Review, in a piece suggestively entitled 'The Politics of Thick Description', said of his former mentor and later contributing writer:

Samuel practised the history of the 'linguistic turn' before the term was invented and, thanks in part to frequent collaboration with Gareth Stedman Jones, elaborated his own cultural materialism which ingeniously turned Foucauldian and post-modern themes inside out (138).

Samuel's notorious enthusiasm for detailed information, Blackburn contended, comprised part of a sophisticated methodological approach for investigating deeper structures of meaning.

Carolyn Steedman, a close friend to Samuel, also perceived greater depth and concealed motivation behind the densely accumulated observations. Steedman, whose research also explored themes of subjectivity and social mentalities, argued:

The standard charge against the history Samuel inspired was of a fanatical empiricism and a romantic merging of historians and their subjects in crowded narratives [...] But it was meaning rather than minutiae that he cared about (53).

She later added, betraying some irritation with her contemporaries (and perhaps even with Samuel himself), that the outward affability could work against the seriousness of his points being recognised:

History Workshop Journal's itemised accounts of the twenty-year battle between empiricism and theory were mostly made at Samuel's instigation. He was always much more interested in ideas than in the detail. But who noticed in 1980, when he made the revolutionary suggestion that one way out of the epistemological wasteland in which socialist historians found themselves, in the death throes of the Marxist historical epic, was that historical explanation 
could remove itself from the hypnotic fix on linear time, could stop dealing with surface concordances (54).

These commendatory perspectives contrast with Stefan Collini's response to Theatre of Memory. Whilst acknowledging Samuel's staggering capacity for empirical detail, Collini suggested that this, in places, restricted the book's capacity to make stronger arguments about the past in contemporary culture. Unlike Steedman who felt this due to some misunderstanding on the behalf of his colleagues, Collini felt the fault to lie with Samuel's own misguided rejection of a privileged role for the 'trained' historian (95-102).

Taking these tributes and accounts ensemble and allowing for differences in interpretative framing, several key observations about the perception of Samuel's public persona can be ventured. Firstly, the importance of Samuel's physical presence reveals the extent to which his ideas and politics were inscribed upon his body and behaviour as much as argued through his texts. In many instances this was framed as comic, his subversion portrayed as mischievous rather than menacing. The showman-ship and energy evident in his public performances, as lecturer or teacher, was unique and daring enough to be exciting and, therefore, memorable.

Secondly, the tributes, in different ways, all acknowledge his capacity to cultivate profoundly personal relationships with both his students and colleagues. This he achieved, in part, by taking a keen interest in the details of their lives and experiences. The ability to generate, within a short period of time, a feeling of intimacy fostered trust and provided him with insight in their lives, enabling him to personalise how he engaged with them.

Finally, several accounts refer to an underlying preoccupation with structures of thought. Through his early communist activism, he had acquired an awareness of mentalities which predated any wider 'cultural turn' in historiography. When channelled into historical and educational work, this existing sensitivity made possible an innovative approach to cultural history and allowed for a degree of success as an adult education tutor. At the same time, they were an unnerving reminder of his previous incarnation. Samuel's early political identity, aspirations and mode operandi had, of course, altered over time but, in another sense, remained largely intact. At the height of the Cold War, he had set out to understand how the arrangement of psychological, as much as physical, conditions informed the world-view of both individuals and social groups. He had done this not only to deepen his political understanding but also to advance his own agenda. 


\section{Conclusion}

Samuel's political practice as a communist organiser-activist and his later role as radical intellectual-educator rested on his capacity to construct an 'agreeable' (or not overtly threatening) and compelling public persona, which encouraged confidence and fostered fascination, so providing him with his 'way in' to people's inner worlds. Undoubtedly, the full potency of this persona belonged to its moment of encounter but, as argued here, by employing strategies of 're-reading' some intimation of its form, techniques and effects can be discerned.

Samuel provides an important optic into the relationship between personality and radical politics, in particular the sort of popular movement politics championed by some amongst the first New Left. As a political project, socialist humanism functioned largely outside of formal structures. Intellectually, it demanded greater scrutiny of mentalities and emphasised social relationships as the fundamental basis of its practical application.

Notably, Samuel was not the only figure within the immediate New Left milieu to be renowned for his striking personal presence. His colleague E.P. Thompson was, in many respects, even more renowned for his compelling public performances. But these were very different from that of the younger man, typically reserved for the crowded lecture theatre or the political platform than for day to day interactions (Anderson, 24; Ree, 'Times Educational Supplement'). For Samuel, a member of the younger ULR generation, this politics of personality was deeply saturated into his everyday interactions, part of a means of accumulating the sort of information, on beliefs, emotions, concealed or implicit structures of meaning, that he would not have been able to access without first achieving a level of trust and intimacy with his informants. Personality and public performance were, then, far from mere packaging for the dissemination of a political argument, they were a form of political action and a historiographical methodology in their own right.

More generally, the figure of Samuel poses an important question about the sort of intellectual work we recognise and, by extension, value. How do we 'see' different forms of intelligence, especially those enacted outside of the written text, and how do we then gauge their impact? In his approach to history, Samuel highlighted the silences within the documentary record, emphasising the full ensemble of individuals (editors, teachers, archivists, informants) and forces (historical, social, cultural) that 'underwrite' all intellectual activity. It is ironic that the champion of those 'hidden from history' should, to some extent, suffer a similar fate. Here, life writing offers a crucial tool for illuminating what lies 'between the lines.' Its intimate lens takes 
in the subtleties implicit in perception and encounter whilst its holistic structure accommodates the sort of social complexity that a politics of practice, such as Samuel's, both recognised and responded to.

Word count: 7451 


\section{Acknowledgements}

I would like to acknowledge Jon Lawrence Karen Fox and Melanie Nolan for discussing this project with me. I would also like to thank the anonymous readers for their thoughtful and constructive comments on an earlier draft. 


\section{Works Cited}

Anderson, Perry, 'Diary: E. P. Thompson', London Review of Books, 15, 20, 21 October (1993): 24.

Black, Lawrence, The Political Culture of the Left in Affluent Britain 1951-64: Old Labour, New Britain? (London: Palgrave Macmillan, 2003).

Blackburn, Robin, "Raphael Samuel: The Politics of Thick Description", New Left Review, I/221, Jan/Feb (1997): 133-138.

Bourdieu, Pierre, The Logic of Practice (Stanford: University of Stanford Press, 1980).

Butler, Judith, Bodies That Matter: On the discursive limits of "sex" (London, New York: Routledge, 1993).

De Certeau, Michel, tr. Stephen Randall, The Practice of Everyday Life (Berkeley: University of California Press, 1984).

Collini, Stefan, 'Speaking with Authority: The Historian as Social Critic', English Pasts: Essays in History and Culture (Oxford: Oxford University Press, 1999), 95-102.

Conquergood, Dwight, 'Performance Studies: Interventions and Radical Research', The Drama Review, 46, 2 (2002): 145-156.

Chun, Lin, The First British New Left (Edinburgh, Edinburgh University Press, 1993).

Davis, Madeleine, 'Reappraising Socialist Humanism', Journal of Political Ideologies, 18, 1 (2013): 57-81.

Dworkin, Dennis, Cultural Marxism in Postwar Britain: History, the New Left, and the Origins of Cultural Studies (Durham: London: Duke University Press, 1997).

Feldman, David and Jon Lawrence, "Introduction: Structures and Transformations in British Historiography”, in David Feldman and Jon Lawrence, eds., Structures and Transformations in Modern British History (Cambridge: Cambridge University Press, 2011)

Gentry, "Ruskin, Radicalism and Raphael Samuel: Politics Pedagogy and the Origins of the History Workshop”, History Workshop Journal, 76, 1 (2013): 187-211.

Goffman, Erving, The Presentation of Self in Everyday Life (London: Penguin, 1990 [1959]). 
Hall, Stuart, “Raphael Samuel: 1934-1996”, New Left Review, I/221, Jan/Feb (1997):119-127.

Hall, Stuart, "The Life and Times of the First New Left", New Left Review, 61, Jan-Feb (2010): 177-196.

Harrison, Brian, "Interview with Raphael Samuel”, 18 September, 1987, 19 Elder Street, London, transcripts held in author's collection.

Harrison, Brian, “Interview with Raphael Samuel”, 20 October 1987, 19 Elder Street, London, transcripts held in author's collection.

Harrison, Brian, "Oxford and the Labour Movement", Twentieth Century British History, 2, 3 (1991): 226-271.

Hennessy, Peter, Having it so Good: Britain in the Fifties (London: Penguin, 2007)

Hoggart, Richard, 'Review of Theatres of Memory', Political Quarterly, 66, 3 (1995): 215216.

Jones, Harriet, "The Impact of the Cold War", in Paul Addison and Harriet Jones, eds., A Companion to Contemporary Britain (Oxford: Blackwell, 2005), 24-26.

Jones, Ken, "Raphael Samuel: Against Conformity", Changing English: Studies in Culture and Education, 5, 1 (1998): 17-26.

Jones, Mervyn, “Obituary: Raphael Samuel”, The Times 11 December, 1996, 1.

Kaye, Harvey, The Education of Desire: Marxists and the Writing of History (London: Routledge, 1992).

Kean, Hilda, "Public History and Raphael Samuel: A Forgotten Radical Pedagogy?", Public History Review, 11 (2004): 51-62.

Kean, Hilda, "People, Historians and Public History; De-mystifying the Process of History Making”, Public Historian, 32, 3 (2010): 25-38.

Keegan, John, "Raphael Samuel: 1934-1996”, The Daily Telegraph, 12 December 1996, 21.

Kenny, Michael, The First New Left: British Intellectuals After Stalin (London: Lawrence and Wishart, 1995). 
Laybourn, Keith, Marxism in Britain: Dissent, Decline and Re-emergence 1945-c2000 (London: Taylor and Routledge, 2006).

Light, Alison, 'Biographical Note on the Text', in Raphael Samuel, Island Stories: Unravelling Britain (London: Verso, 1998).

Light, Alison, “Minna Keal 1909-1999”, The Guardian, 24 November 1999, 24.

Martin, Paul, "Look, See, Hear" in Geoff Andrews, Hilda Kean and Jane Thompson, eds., Ruskin College: Contesting Knowledge, Dissenting Politics (London: Lawrence and Wishart, 1999), 146-147.

Matthews, Wade, The New Left, National Identity and the Break Up of Britain (Leiden: Boston: BRILL, 2013).

May, Alex, 'Keal, Minna (1909-1999)', Oxford Dictionary of National Biography (Oxford: Oxford University Press, 2004).

Morgan, Kevin, 'The Communist Party and the Popular Front 1935-1938', Against Fascism and War (Manchester: Manchester University Press, 1989), 33-55.

Pilmott, Ben, "Socialism mourns a historian of intellect and humanity", New Statesman, 20 December 1996, 7.

Prescott, John, “Genuine Love for Others”, The Guardian, 11 December 1996, 16.

Purdie, Bob 'Long-haired Intellectuals and Busy Bodies', Ruskin College: Contesting Knowledge, Dissenting Politics (London: Lawrence and Wishart, 1999),

Ree, Jonathan, ‘A Theatre of Arrogance', Times Higher Educational Supplement, 5 June 1995.

Rowbotham, Sheila, "Some Memories of Raphael”, New Left Review, I/221, Jan-Feb (1997): 128-132.

Samuel, Ralph, 'Letter to Stuart Hall', 15 ${ }^{\text {th }}$ November, 1956, RS.1: New Left/001, '1956', Raphael Samuel Archive, Bishopsgate Institute, London.

Samuel, Ralph, 'Letter to Stuart Hall', $1^{\text {st }}$ December, 1956, RS.1: New Left/001, '1956', Raphael Samuel Archive, Bishopsgate Institute, London.

Samuel, Ralph and Taylor Charles, 'A Left notebook', Universities and Left Review, 1, 2 (1957): 79-80. 
Samuel, Raphael, 'Afterword: History Workshop 1966-1980', in Raphael Samuel, ed., People's History and Socialist Theory (London: Routledge Paul, 1981), 410-417.

Samuel, Raphael, Theatres of Memory (London: Verso, 1994).

Samuel, Raphael, The Lost World of British Communism (London: Verso, 2006).

Saville, John, Memoirs From the Left (London: Merlin, 2003).

Schechner, Richard, Performance as Theory (London, New York: Routledge, 1988 [1977]).

Schwarz, Bill, "Keeper of our shared memory” The Guardian 10 December 1996, 16.

Schwarz, Bill, 'History on the Move: Reflections on History Workshop', Radical History Review, 57 (2002): 202-220

Scott-Brown, Sophie, "The Histories of Raphael Samuel: A Portrait of a People's Historian" (unpublished $\mathrm{PhD}$ thesis, ANU, 2015).

Segal, Lynne, 'Lost Worlds: Political Memoirs of the Left in Britain', Radical Philosophy, 121, Sept-Oct (2003): 6-23.

Steedman, Carolyn, "Raphael Samuel: 1934-1996", Radical Philosophy, March/April (1997):52-54.

Stedman Jones, Gareth, "Raphael Samuel: 1934-1996”, The Independent, 10 December 1996, 12.

Thompson, Dorothy, 'On the Trail of the First New Left', New Left Review, I/215, Jan-Feb (1996): 93-100.

Thompson, E.P., 'Letter to Raphael Samuel and Michael Barrett Brown', $6^{\text {th }}$ February 1957 , RS.1: New Left/002, '1957’, Raphael Samuel Archives, Bishopsgate Institute, London.

Thompson, E.P., 'Socialist Humanism: Epistle to the Philistines', New Reasoner, 1 (1957): 105-143.

Thompson, E.P., 'Socialism and the Intellectual', Universities and Left Review, 1 (1957): 3136.

Williams, Raymond, Culture and Society 1780-1950 (London: Chatto and Windus, 1958).

Wright, Patrick, "Heritage Clubs Slug It Out”, The Guardian, 4 February 1995, 29. 
